2014s-33

\title{
Availability of Family-Friendly Work Practices and Implicit Wage Costs: New Evidence from Canada
}

\author{
Ali Fakih
}

\begin{tabular}{c}
\hline Série Scientifique \\
Scientific Series
\end{tabular}

\author{
Montréal \\ Juin 2014
}

(C) 2014 Ali Fakih. Tous droits réservés. All rights reserved. Reproduction partielle permise avec citation du document source, incluant la notice (C).

Short sections may be quoted without explicit permission, if full credit, including (C) notice, is given to the source.
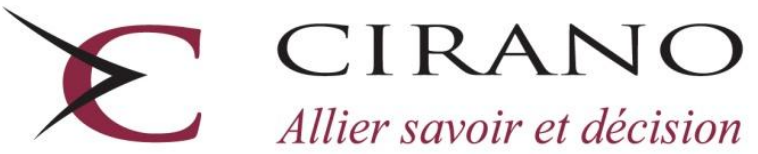

Allier savoir et décision

Centre interuniversitaire de recherche en analyse des organisations 


\section{CIRANO}

Le CIRANO est un organisme sans but lucratif constitué en vertu de la Loi des compagnies du Québec. Le financement de son infrastructure et de ses activités de recherche provient des cotisations de ses organisations-membres, d'une subvention d'infrastructure du Ministère de l'Enseignement supérieur, de la Recherche, de la Science et de la Technologie, de même que des subventions et mandats obtenus par ses équipes de recherche.

CIRANO is a private non-profit organization incorporated under the Québec Companies Act. Its infrastructure and research activities are funded through fees paid by member organizations, an infrastructure grant from the Ministère de l'Enseignement supérieur, de la Recherche, de la Science et de la Technologie, and grants and research mandates obtained by its research teams.

\section{Les partenaires du CIRANO}

\section{Partenaire majeur}

Ministère de l'Enseignement supérieur, de la Recherche, de la Science et de la Technologie

\section{Partenaires corporatifs}

Autorité des marchés financiers

Banque de développement du Canada

Banque du Canada

Banque Laurentienne du Canada

Banque Nationale du Canada

Bell Canada

BMO Groupe financier

Caisse de dépôt et placement du Québec

Fédération des caisses Desjardins du Québec

Financière Sun Life, Québec

Gaz Métro

Hydro-Québec

Industrie Canada

Intact

Investissements PSP

Ministère des Finances et de l'Économie

Power Corporation du Canada

Rio Tinto Alcan

Ville de Montréal

\section{Partenaires universitaires}

École Polytechnique de Montréal

École de technologie supérieure (ÉTS)

HEC Montréal

Institut national de la recherche scientifique (INRS)

McGill University

Université Concordia

Université de Montréal

Université de Sherbrooke

Université du Québec

Université du Québec à Montréal

Université Laval

Le CIRANO collabore avec de nombreux centres et chaires de recherche universitaires dont on peut consulter la liste sur son site web.

Les cahiers de la série scientifique (CS) visent à rendre accessibles des résultats de recherche effectuée au CIRANO afin de susciter échanges et commentaires. Ces cahiers sont écrits dans le style des publications scientifiques. Les idées et les opinions émises sont sous l'unique responsabilité des auteurs et ne représentent pas nécessairement les positions du CIRANO ou de ses partenaires.

This paper presents research carried out at CIRANO and aims at encouraging discussion and comment. The observations and viewpoints expressed are the sole responsibility of the authors. They do not necessarily represent positions of CIRANO or its partners.

ISSN 2292-0838 (en ligne)
Partenaire financier

Enseignement supérieur. Recherche, Science et Technologie Québec 봄ำ 


\title{
Availability of Family-Friendly Work Practices and Implicit Wage Costs: New Evidence from Canada
}

\author{
Ali Fakih *
}

\section{Résumé/abstract}

Using Canadian linked employer-employee data covering the period 1999-2005, I examine the determinants of the availability of family-friendly "care" practices and the impact of such practices on wages. The results show that the provision of family-friendly practices is not mainly derived from socio-demographic characteristics of workers but rather from joband firm-related factors. The findings also reveal that there is a trade-off between the provision of family-friendly practices and earnings indicating the existence of an implicit market in which workers face reductions in their wages. This result supports the hypothesis that family-friendly benefits are to some extent conceived as a gift or a signal that employers care about employees' family responsibilities and, in return, employees are willing to "buy" these practices and thus accept a wage offset.

Mots clés : Family-friendly "care” practices, linked employer-employee data, simultaneous probit model, wage equation.

Codes JEL : J13, J32, J70.

\footnotetext{
* Department of Economics, Lebanese American University, P.O. Box: 13-5053 Chouran, Beirut 11022801 , Lebanon. Tel.: +961-1786456; Fax: +961-1-867098. E-mail address: afakih@lau.edu.lb. Center for Interuniversity Research and Analysis on Organizations (CIRANO), Montreal, Canada. Institute for the Study of Labor (IZA), Bonn, German.
} 


\section{Introduction}

Firms as well as governments invest considerable resources in family-friendly work practices that attempt to reduce the negative consequences generated by the work-family conflict. ${ }^{1}$ It is surprising, therefore, that the availability of such practices is quite modest in most firms (Bloom et al., 2011; Evans, 2001). For example, childcare services are available in $5.3 \%$ of firms in Germany, 3.6\% of firms in Great Britain and 7.6\% of firms in the U.S. (see Bloom et al., 2011: table $1 b)$. Moreover, there is no agreement among scholars as to whether, and to what extent, the availability of family-friendly practices has a bearing on employees' wages. For instance, Heywood et al. (2007) find that some family-friendly practices are associated with an implicit reduction in wages. The objective of this paper is twofold. I first examine the determinants of the availability of three family-friendly "care" practices: assistance for childcare, assistance for elder care and extended health care. ${ }^{2}$ Second, I investigate the relationship between such practices and wages. These family-friendly care programs are a possible way to promote workers' health and provide practical assistance for these workers who have to care for elderly and dependent individuals (Osterman, 1995: 682).

Despite the importance of family-friendly practices in reducing the negative consequences generated by the work-family conflict, there is relatively little empirical evidence on the determinants of the availability of such practices. The common argument in the literature is that working for a firm providing such benefits does not guarantee that family-friendly practices will be available for all employees in that firm (e.g., Gray and Tudball, 2003: 270; Whitehouse and Zetlin, 1999: 230). Budd and Brey (2003: 87) argue that employees are not equally aware of the availability of family-friendly work practices. Gray and Tudball (2003) find that family-friendly practices are more available to managers, professionals and administrators.

\footnotetext{
1 Work-family conflict is an important issue for firms because of the cost related to the dissatisfaction at work (Duxbury and Higgins, 2003) and the increase in the absenteeism rate (Vistnes, 1997). Moreover, work-family conflict has negative consequences on the physical and mental health of employees, which may lead to an increase in health care spending (Duxbury et al., 1999).

${ }^{2}$ Extended health care is a part of fringe benefits and complements the coverage offered by provincial health insurance plans. Extended health care contributes to the objective of ensuring a better reconciliation of work and family life because it can affect all employee family members. It contributes to improving the physical and mental health of employees and their dependents (Human Resources and Skills Development Canada (HRSDC), 2000). O'Brien (2003: 14) argues that firms provide extended health care to improve workers' health, which may increase productivity and organizational performance and reduce absenteeism and turnover at work. Additionally, firms might benefit from providing such health insurance by recruiting and retaining high-quality workers. Empirical studies also show that the availability of health benefits reduces job mobility (Anderson, 1997).
} 
They note that governments must consider policies that favor a better availability of family-friendly practices for all employees, regardless of their occupation, work status and level of education. Budd and Mumford (2006) conclude that the effect of the independent variables on the availability of family-friendly practices is not similar across all measures of these practices. They show, however, that variables with the greatest impact on the availability of family-friendly practices are average current job tenure of the workforce; proportion of the part-time workforce; proportion of the workforce educated past secondary school; proportion of the female workforce; proportion of the workforce with children; and workplaces with at least 500 employees. More recently, Bloom et al. (2011) show that firms with a higher proportion of qualified workers and women managers offer more family-friendly practices.

There are many reasons to doubt that workers provided with family-friendly practices face an implicit reduction in their wages. That is, there may exist a significant wage premium associated with the availability of such practices. According to the economic theory, in a competitive labour market, wages are usually higher in jobs with less desirable characteristics and more risks (Rosen, 1974). This author justifies such a phenomenon through the existence of an implicit market that allocates job attributes valued by workers but that are costly for firms. Equivalently, family-friendly practices could be considered benefits for workers and costs for firms. I postulate that wages are lower when firms provide such family-friendly practices. A number of empirical studies corroborate this hypothesis. Heywood et al. (2007: 296) argue that firms attract employees who implicitly accept a salary reduction to offset the cost of providing family-friendly practices. They note that the implicit costs in employee salaries induce the government to intervene in the market of family-friendly practices. By the same token, Baughman et al. (2003) find that flextime and assistance for childcare are associated with salary reduction. In contrast, Gariety and Shaffer (2001) find that the availability of family-friendly practices is positively correlated with earnings. They argue that firms reward their most productive employees with such practices. Johnson and Provan (1995) find a positive impact of employer-sponsored childcare on earnings. However, they find that flextime is not significantly associated with wages for men. Thus, the net influence of family-friendly practices on wages remains an empirical issue, and further investigation may be warranted.

In this paper, I provide additional evidence on the availability of family-friendly practices by tackling the case of Canada. Specifically, I examine two questions. First, what are the worker 
and firm characteristics that affect the provision of family-friendly practices? Second, is there a trade-off between wages and the provision of family-friendly practices? My paper is conceptually similar to Budd and Mumford (2006) and Heywood et al. (2007), however, it improves on the previous works in two ways. I first estimate a simultaneous probit model while allowing unobserved worker and firm effects to be correlated across different models. This model allows us to determine whether family-friendly practices are available simultaneously in the same workplace. Second, I take into account unobserved effects in the wage equation. I resort to instrumental variables to control for the potential endogeneity of the firm's decision: it is plausible that firms with the most family-friendly practices are also those that may have considerable impact on wages. I use the Workplace and Employee Survey (WES) 1999-2005 dataset provided by Statistics Canada. The use of the Canadian WES data is relevant because (1) the survey provides information on a representative sample of Canadian establishments with information on their employees at different points in time; (2) the survey includes detailed demographic, job and firm characteristics; (3) the linked nature of the survey enables controlling for unobserved firm heterogeneity; and lastly, (4) the longitudinal character of the survey allows us to take into account unobserved worker heterogeneity. The paper first provides a brief summary of the conceptual framework, and then presents the data along with the descriptive statistics of variables used in the analysis. Next, the econometric specification is discussed followed by the empirical results. The final section provides concluding remarks.

\section{Conceptual framework}

\subsection{Availability of family-friendly practices}

Family-friendly practices can be represented on three levels (see Figure 1 below). First, a firm may or may not offer family-friendly practices. For example, firms may offer such practices as a means to attract certain types of employees, where family-friendly practices could be considered a component of fringe benefits packages and are normally specified in the employment contract. Firms may also offer family-friendly practices as a human resource practice geared towards performance improvement (Bloom et al., 2011: 343). Second, if firms offer family-friendly practices, employees may or may not have access to these practices. Lastly, if employees have access to such practices, they may or may not decide to use them. In this paper, I focus on the first level. 
Figure 1: Relationship between availability, access and usage of family-friendly practices

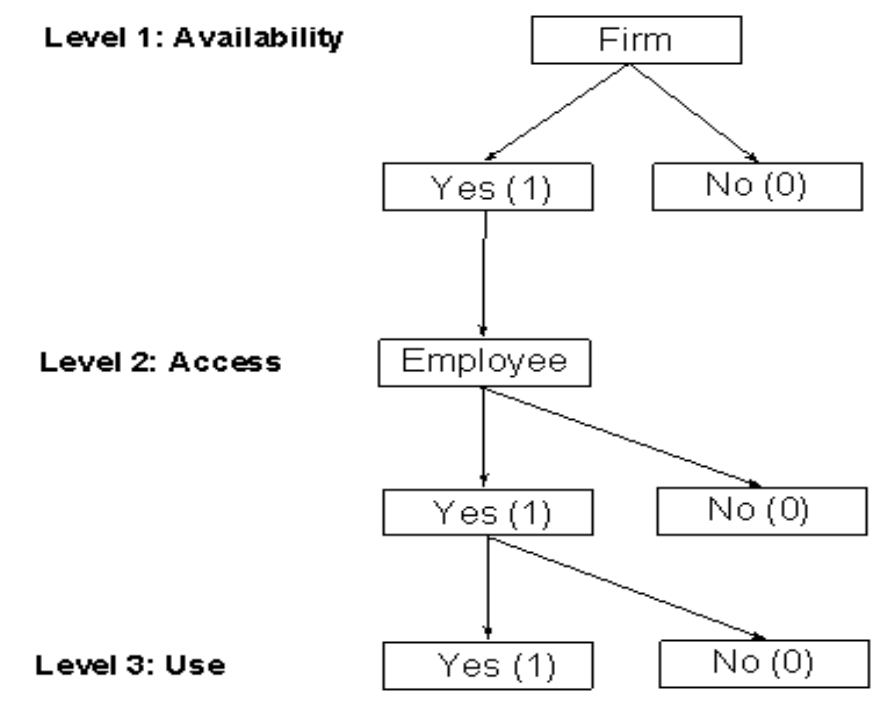

Analyzing the determinants of the availability of family-friendly practices (i.e., fringe benefits) and their relation to wages involves a firm's decision regarding offering benefits and a worker's decision whether to choose a job with a particular combination of wage and fringe benefits, where workers have heterogeneous preferences for family-friendly practices (Senesky, 2005: 749; Rebitzer and Taylor, 1995). The determinants of such practices must therefore be addressed, taking into account both worker and firm characteristics. For example, demographic changes such as the higher participation rates of women in the labour market have increased the demand for family-friendly practices (Bardoel et al., 1999; Budd and Mumford, 2006). Following Bardoel et al. (1999) and Budd and Mumford (2006), I include a set of demographic characteristics that are likely to increase the potential demand for family-friendly practices. Specifically, I include variables on gender, marital status, race, age, immigrants, number of children, single-parent families, income and a measure of health.

An important factor that may also influence the probability of providing family-friendly practices is the level of human capital accumulation, which is measured by seniority, labour market experience and education. Seniority represents an employee's level of stability under his or her employer, and family-friendly practices, which are considered non-pecuniary benefits, are expected to increase with seniority. Regarding labour market experience, one can assume that family-friendly work obtained with an employer is not lost when workers change employers. We 
would expect that workers who have accumulated more years of education enjoy more family-friendly practices. The theory of human capital predicts that level of education is inversely proportional to the time allotted to household tasks (Becker, 1985). The greater the education gap between employees is, the more employees with higher education are expected to demand family-friendly benefits.

The labour supply literature, which integrates job characteristics into the neoclassical labour supply model (e.g., Senesky, 2005), suggests that firms provide family-friendly practices if they contribute to increasing firm's profits. In a context in which individuals choose a particular combination of work hours, fringe benefits and wages based on their unobservable preferences, job and firm characteristics are likely to play a role in the provision of family-friendly practices. The rich structure of the dataset allows us to include a variety of joband firm-related characteristics. Following Budd and Mumford (2006), Evans (2002) and Gray and Tudball (2003), I include variables on work schedules, job promotion, supervisory positions, union status, workforce characteristics and firm size indicators. For example, some firms may offer family-friendly practices only to managers as additional benefits. In addition, large firms are likely to have more formal human resource management and policies than smaller ones. We therefore would expect that larger firms meet fringe benefits entitlement provisions more than smaller firms.

\subsection{Family-friendly practices and wages}

The literature on the link between family-friendly practices and wages is divided into two strands. According to the first strand, family-friendly practices are considered an important component of fringe benefits package and are normally specified in employment contracts. This state of affairs would lead to the presumption that obtaining more family-friendly practices is an indicator of a higher wage. The positive relationship between family-friendly practices (non-pecuniary job benefits) and wages is consistent with job search models (e.g., Hwang et al., 1998; Lang and Majumdar, 2004). According to those models, firms' heterogeneity in matching values implies that some firms will propose a combination of high-wage and family-friendly practices that best balances the firms' and workers' preferences (e.g., to attract and retain high-quality workers or to reduce turnover rate). Arthur and Cook (2004) provide a different explanation of the positive relationship between family-friendly practices and wages. They find 
that work-family human resource decisions are positively and significantly correlated with firm profits. By the same token, Perry-Smith and Blum (2001) find that offering family-friendly practices enhance the performance of a firm. Bloom et al. (2011) find a positive relationship between family-friendly practices and firm productivity. However, this relationship disappears after controlling for the quality of management practices.

The second strand of literature predicts that there is a trade-off between employer-provided family-friendly practices and wages. Therefore, there is a hedonic equilibrium in which jobs with more family-friendly practices might be associated with lower wages. Duncan and Stafford (1980: 355-356) argue that, because of the heterogeneity in a firm's ability to bear the costs associated with offering family-friendly practices, a hedonic equilibrium could occur in firms offering such practices. Gruber and Krueger (1991: 113) argue that an important portion of the cost of providing mandated fringe benefits is shifted to employees through lower wages. Heywood et al. (2007: 278) note that firms try to offset these costs by reducing employees' wages. This result is in line with hedonic compensation theory (Rosen, 1974). This theory implies that two jobs that differ in terms of their non-pecuniary benefits (e.g., family-friendly practices) will offer different wages. For example, if two employers offer the same salary but the first employer offers more family-friendly practices than the second, in this case the first employer is more beneficial to the employee. Rebitzer and Taylor (1995) show that labour market equilibrium may be characterized by less than the optimal combination of working hours and fringe benefits because work preferences are heterogeneous and unobserved by firms.

\section{Data}

I use data from the Workplace and Employee Survey (WES) conducted by Statistics Canada. The WES has been conducted annually since 1999 and came to an end in 2005. I use all 7 years of available data (1999-2005). The WES is both longitudinal and linked in that it documents the characteristics of workers and workplaces over time. The target population for the workplace component of the survey is defined as the collection of all Canadian establishments that paid employees in March of the year of the survey. Those establishments are followed over time with the periodic addition of samples of new locations to maintain a representative sample. The WES does not cover firms located in the Yukon, the Northwest Territories or Nunavut or the public administration, the livestock production industry, fisheries or hunting or trapping operations. For 
the employee component, the target population is the collection of employees working or on paid leave in the workplace target population. Employees are sampled from lists provided by the selected workplaces. For every workplace, a maximum of 24 employees are selected, and for establishments with less than 4 employees, all employees are sampled.

The WES selects new employees and workplaces in odd years. The WES is therefore representative of employees only for the resampling years (1999, 2001, 2003 and 2005). The survey consists of a follow-up of the initial sample chosen in 1999, to which Statistics Canada adds a sample of new firms every two years. The initial sample comprises 23,540 employees in 1999, 20,167 (85.6\%) of whom were also present in 2000. In 2001, 20,352 employees were resampled, and 16,813 (82.6\%) of them were contacted again in 2002. In 2003, 20,834 employees were resampled, and 16,804 (80.6\%) of them were contacted again in 2004. Lastly, 24,197 employees were resampled in the last year of the survey. The final sample comprises 81,054 observations after eliminating observations with missing values for some covariates.

The rich structure of this survey allows us to control for a variety of factors affecting the availability of family-friendly practices. I construct three dummy variables that define the availability of family-friendly practices in the workplace. These variables take the value one if the employee answers "yes" to the question regarding whether a family-friendly practice is available to an employee in the workplace and zero otherwise. The dummies of family-friendly practices used in this paper are 1) assistance for childcare, 2) assistance for elder care and 3) extended health care. Wage variable used in this paper is the hourly wage.

The WES dataset contains a rich set of variables describing both worker and firm characteristics. From the worker questionnaire, I use detailed explanatory variables on demographic characteristics, human capital, and on job-related characteristics. From the workplace questionnaire, I use variables on workforce characteristics and firm size indicators. Regarding worker characteristics, the following variables are constructed as dummies: gender (female $=1$ ), marital status (married $=1$ ), if the worker is from the Black minority group with "White" as the reference group, age is defined in years, if the worker is immigrant (immigrant = 1), presence of children aged 0 to 18 (yes =1), if the family is a one-parent family (single-parent $=1$ ), total family income from different sources, a dummy variable if the employee does not have any limitation in work due to health issue. Seniority (length of a worker's employment within a firm) is measured in years. Experience (number of years of full time work) is also measured in 
years. The WES only lists degrees held by each worker. Accordingly, we use this information to assess the role of education. We construct four dummies for education each coded as yes $=1$. We include the following dummies: vocational diploma or some college, completed college or some university, bachelor or higher education completed, and industrial training or other. Working less than 30 hours per week is considered part-time work. Work arrangements dummies are defined as follows: reduced work week (following a special agreement with the employer) and compressed week (working more hours in a day to reduce the number of working days per week). Job promotion is a dummy variable equal to one if the worker obtained a promotion since he/she started working for this employer. Supervisor is also a dummy variable equal to one if the worker supervises the work of other workers. Unionization is equal to one if the worker is a member of a union or covered by a collective bargaining agreement. A dummy variable equals to one if the employer offers job training. Facing problems in filling vacant positions (dummy = 1). Firm size is constructed from four dummies: small (less than 20 employees); medium (20 to 99); large (100 to 499); and very large (500 employees or more).

\subsection{Descriptive statistics}

Table 1 presents an analysis of the variances of the availability to each of the family-friendly practices broken down into the overall, between-firm and within-firm components for the whole sample, i.e., 1999-2005. Differences in the availability of family-friendly practices between employees can be separated into a component due to the variation between firms (between-firm variation) and into a component due to differences between employees who work in the same firm (within-firm variation). If all of the employees in the same firms have the same availability of family-friendly practices, the within-firm variation will be zero and all differences between employees will be due to differences between firms. In contrast, if there is no correlation between employees working in the same firm, the level of variation in the within-firm and between-firm components will be the same (Gray and Tudball 2003). I find that the proportion of employees who report having assistance for childcare is $4.4 \%$. I also find that the overall standard deviation is 0.205 for assistance for childcare. The between- and within-firm components indicate that the standard deviation of the variation between-firms is 0.058 , compared to 0.204 for that of the variation within-firms. This discrepancy indicates that the variation between workers granted childcare is greater within firms than between firms. That is, 
two employees from different firms are more likely to report having assistance for childcare than two other employees working in the same firm. As in the case of assistance for childcare, I find that the between-firm variation is less than the within-firm variation for assistance for elder care and extended health care.

Tables 2 and 3 present the summary statistics of the variables used in the empirical analysis for employees and employers, respectively. In Table 2, the sample shows that $52.1 \%$ of employees are females and that $56.6 \%$ are married. I control for employee race with the variable black, who represent $1.1 \%$ of the sample. The average seniority is approximately 8 years, and the average work experience is close to 16 years. The average age of employees in the sample is 40 years. Immigrants represent $17.5 \%$ of the sample. Regarding education, I find that approximately $33 \%$ of the employees have a vocational diploma or some college education, $43.3 \%$ have completed college or have some university education, $27 \%$ have a bachelor's degree or higher and approximately $12.7 \%$ have industrial training or other education. In Table 3, I find that most of the workplaces operate in the retail sector $(31.7 \%)$, followed by education and health services and transport (12.1\%). Small firms (less than 20 employees) represent $87.4 \%$ of the sample, whereas the percentage of medium firms (20 to 99) is approximately 10.8\%; the categories large firms (100 to 499) and very large firms (500 employees or more) represent $1.5 \%$ and $0.2 \%$ of the sample, respectively. It should be noted that I use the sample weight to account for the complex survey design in all of the descriptive statistics. Lastly, it is impossible to disclose the minimum and the maximum values because of Statistics Canada's confidentiality policy.

\section{Empirical strategy}

I first use a simultaneous probit model to examine the determinants of the availability of family-friendly practices while allowing worker and firm unobserved effects to be correlated across different models. Second, I estimate the trade-off between the availability of such practices and wages while taking unobserved effects into account.

\subsection{Correlated probit model}

Let $P_{i j t}^{*}$ denote the net benefits accrued to an employee $i \in(1, \ldots, I)$ in firm $j \in(1, \ldots, J)$ at 
time $t \in(1, \ldots, T)$ from having family-friendly practices. ${ }^{3}$ The probit model can be expressed as follows:

$$
P_{i j t}^{*}=\beta X_{i j t}+\gamma Z_{j t}+\theta_{i j}+\psi_{j}+\varepsilon_{i j t}
$$

where $X_{i j t}$ represents a vector of variables describing worker characteristics; $Z_{j t}$ represents a vector of variables describing firm characteristics to which the worker is linked. The additional parameters $\theta_{i j}$ and $\psi_{j}$ capture the impact of unobserved worker and firm characteristics, respectively. $\varepsilon_{i j t}$ is the error term.

Worker effect can be interpreted as a measure of unobserved characteristics (e.g., different preferences, ability, motivation, ambition) that vary between employees and may affect the probability of having family-friendly work practices. Workplace effect is a measure of firm-specific unobserved characteristics common to all workers of the same workplace. For example, it can be interpreted as a measure of family-friendly practices offered to employees of the same firm.

The identification of the worker and firm effects is made possible through the longitudinal and linked nature of the data. Identification of the firm effect is based on repeated observations of workers from the same firm. However, including unobserved pure worker heterogeneity is not possible because we do not observe worker mobility between firms in our data. Therefore, the identification of the worker effect is possible through the employeremployee relationship $\left(\theta_{i j}\right)$ because we have repeated observations on the same worker over time. I assume that unobserved characteristics are independent of observable characteristics.

The variable $P_{i j t}^{*}$ is not observed because it is a latent variable. Instead, we observe whether or not family-friendly practices are available. Hence, I define the following probit rule:

$$
P_{i j t}=\left\{\begin{array}{l}
1 \text { if } P_{i j t}^{*} \geq 0 \\
0 \text { if } P_{i j t}^{*}<0
\end{array}\right.
$$

where $P_{i j t}$ is a binary variable that equals one when the employee states that the firm provides family-friendly practices throughout the year and zero otherwise. I assume that both worker and

\footnotetext{
${ }^{3}$ In the WES questionnaire, the information regarding the availability of family-friendly work practices is given in the "employee" component. In other words, employees answer the question whether or not the firm provides such practices.
} 
workplace heterogeneity are normally distributed with zero mean.

I estimate equation (1) simultaneously for each type of family-friendly work practice while allowing the unobserved workplace and worker heterogeneity components to be correlated across models. Estimating the correlation between each type of family-friendly practice will be informative in determining whether these practices are substitutes or complements. Thus, I add the superscript $d$ to the latent model (1), where $d=1$ (assistance for childcare), $=2$ (assistance for elder care) or $=3$ (extended health care). Unobserved heterogeneity components $\theta_{i j}^{d}$ and $\psi_{j}^{d}$ follow a trivariate normal distribution ${ }^{4}$ :

$$
\left(\begin{array}{l}
\theta_{i j}^{1} \\
\theta_{i j}^{2} \\
\theta_{i j}^{3}
\end{array}\right): N\left(\left[\begin{array}{l}
0 \\
0 \\
0
\end{array}\right],\left[\begin{array}{ccc}
\sigma_{\theta}^{11} & \sigma_{\theta}^{12} & \sigma_{\theta}^{13} \\
\cdot & \sigma_{\theta}^{22} & \sigma_{\theta}^{23} \\
\cdot & \cdot & \sigma_{\theta}^{33}
\end{array}\right]\right)
$$

and

$$
\left(\begin{array}{l}
\psi_{j}^{1} \\
\psi_{j}^{2} \\
\psi_{j}^{3}
\end{array}\right): N\left(\left[\begin{array}{l}
0 \\
0 \\
0
\end{array}\right],\left[\begin{array}{ccc}
\sigma_{\psi}^{11} & \sigma_{\psi}^{12} & \sigma_{\psi}^{13} \\
\cdot & \sigma_{\psi}^{22} & \sigma_{\psi}^{23} \\
\cdot & \cdot & \sigma_{\psi}^{33}
\end{array}\right]\right)
$$

where the diagonal of the covariance matrices (3) and (4) are the variances of $\left(\theta_{i j}^{1}, \theta_{i j}^{2}, \theta_{i j}^{3}\right)$ and $\left(\psi_{j}^{1}, \psi_{j}^{2}, \psi_{j}^{3}\right)$, respectively. This specification entails the estimation of 12 parameters for the distribution of unobserved heterogeneity components. However, I settle on a slightly less involved specification to facilitate the likelihood calculation, where I assume that

$$
\theta_{i j}^{d}=\gamma^{d} \theta_{i j}, \text { with } \theta_{i j}: N(0,1)
$$

and

$$
\psi_{j}^{d}=\vartheta^{d} \psi_{j}, \text { with } \psi_{j}: N(0,1)
$$

This last specification requires the estimation of only 6 parameters $\left(\gamma^{d}, \vartheta^{d}\right.$; where $\left.d=1,2,3\right)$. The parameters of the distribution have interesting interpretations. For example, if $\sigma_{\theta}^{12}$ is positive, unobserved worker characteristics that are associated with more assistance for childcare are also associated with more assistance for elder care. I use maximum likelihood methods to obtain estimates for the parameters and their standard errors. Given that there is no closed-form

\footnotetext{
${ }^{4}$ Simultaneity is derived from worker and firm effects. Indeed, I are interested in the information given by the covariance matrix of the effect $\theta_{i j}^{d}$ and that of the effect $\psi_{j}^{d}$.
} 
solution to the integral, the maximum likelihood estimates are computed by approximating the normal integral using a numerical integration algorithm based on adaptive Gauss-Hermite Quadrature. This algorithm selects a number of points and weights such that the weighted points approximate the normal distribution.

\subsection{Wage equation}

Turning to the estimation of the relationship between the availability of family-friendly practices and wages, I use the Two Stages Least Squares (2SLS) method to solve the problem of simultaneity in which the availability of family-friendly practices is determined simultaneously with wages. ${ }^{5}$ It is plausible that firms with the most family-friendly practices are also those that may have considerable impact on wages. Thus, the assumption of the exogeneity of the explanatory variable that indicates whether or not the family-friendly practice is available in the firm may be violated. Because the availability of family-friendly practices is endogenous, the estimator obtained by the OLS method could be biased.

In our case, this procedure consists of instrumenting the family-friendly practices by variables that influence the probability of workers being provided family-friendly practices but will not affect wages. Specifically, I use the following instruments: whether or not the employee has dependent children or young children and whether or not there is a dispute, complaint or grievance system in the workplace. Heywood et al. (2007) mention that having dependent children or young children is correlated with family-friendly practices. For the second variable, the assumption is that the existence of a formal procedure to represent workers may improve aspects of work and therefore be beneficial for workers. Workers could therefore assume that the firm cares about their family responsibilities, which can affect the supply of family-friendly practices. Moreover, the underlying assumption is that these instruments are not correlated with the error term.

\section{Results}

\subsection{Determinants of the availability of family-friendly practices}

This section examines the determinants of the probability that family-friendly practices are

\footnotetext{
${ }^{5}$ Wooldridge (2002: 623-625) shows that there are no special considerations in using the 2SLS method when the endogenous explanatory variable is binary.
} 
available to employees using a correlated probit model. Table 4 reports the marginal effects weighted by sampling weights. In all models, the dependent variable is a binary variable which equals one when a family-friendly practice is available and zero otherwise. I control for occupation, industry and year in all specifications.

\subsubsection{Employee characteristics}

Column (1) presents the results for childcare while columns (2) and (3) present the results for elder care and extended health care, respectively. The results reveal that being a woman increases the probability of having assistance for childcare. However, the result indicates that women are less likely to have assistance for elder care. It is possible that women may not have much time for elderly persons because women are more involved in child care and spend more time with their children, which may suggest that men have more time than women do and consequently can allocate more time for elderly persons. These results are consistent with those reported in previous studies (e.g., Bardoel et al., 1999; Budd and Mumford, 2004; Budd and Mumford, 2006; Heywood and Jirjahn, 2009). The estimated marginal effect for the extended health care variable is positive but not statistically significant.

The results also show a negative and statistically significant effect of marital status on the probability of having assistance for elder care, i.e., married employees are less likely to have assistance for elder care. It is possible that in certain firms single employees have more dependent elders for which to care. Perhaps surprisingly, I find that immigrants are more likely to have assistance for childcare and elder care. One might speculate that immigrants face more difficulties than others in the workplaces, which might lead to an increase in the provision of such practices. As in Osterman (1995), Bardoel et al. (1999) and Budd and Mumford (2006), employee age is not statistically significant associated with the provision of the three family-friendly practices.

Contrary to the predictions of the neo-classical theory stating that labour market supply and demand pressures lead a number of firms to offer family-friendly practices (see the discussion provided in Budd and Mumford, 2006: 93-94), the results highlight a negative effect of the number of children on the probability of having assistance for childcare, assistance for elder care and extended health care. However, this effect is small in magnitude and is statistically significant only for assistance for childcare in accordance with previous literature (e.g., Bardoel 
et al., 1999) in the case of firms in Australia and Budd and Mumford (2006) in the case of firms in Britain).

With respect to the human capital variables, I find that only the category "Bachelor's degree or higher", which is the highest level of education, is associated with a greater probability of having assistance for elder care and extended health care. It is indeed logical to believe that positions requiring a high level of education are more likely to offer family-friendly practices. However, categories such as "Vocational diploma or some college", "Completed college or some university" and "Industrial training or other" have no effect on such practices. It is therefore difficult to conclude if education is a predictor of these family-friendly practices. I also find that seniority is not an important determinant for the availability of such practices. It is plausible to conclude that firms do not reward employee seniority by offering more family-friendly practices. This result was also reported by Osterman (1995) and Budd and Mumford (2006).

\subsubsection{Job characteristics}

The results show that part-time employees are less likely to have assistance for all types of care. Indeed, part-time works are generally less profitable in terms of fringe benefits, and these employees are less likely to participate in available benefit plans such as family-friendly practices. In addition, it is possible that these part-time employees are attracted to jobs that do not offer family-friendly practices.

I find that workers with compressed work week schedules (i.e., more hours worked to reduce the number of work days) are more likely to obtain assistance for childcare and elder care. The results also indicate a positive and statistically significant effect of the variable promotion received on the three types of family-friendly practices. By the same token, I find that holding a supervisory position is positively correlated with the probability of having assistance for childcare and for elder care. Supervisors are often overburdened by responsibilities, which may lead them to spend more time at work and increase their demand for family-friendly practices. These results suggest that tasks requiring more responsibilities are positively associated with the availability of family-friendly practices. Past research has highlighted the positive effects of supervisors in terms of work-family conflict (e.g. Valcouret al. 2011). 
Contrary to results reported in previous empirical studies (e.g., Budd and Mumford, 2006; Heywood and Jirjahn, 2009), unions do not influence the availability of the three family-friendly practices. This result lends support to Osterman's (1995) finding that the probability of having such practices is not influenced by being unionized in the U.S. This result could be explained by the low percentages of unionization in our sample (28\% and 26\% in 1999 and 2005, respectively). These numbers are quite close to the figure obtained by Osterman (1995) in the U.S., approximately $19 \%$. However, the percentage of union workers was $60 \%$ in Britain (Budd and Mumford, 2006) and 59\% in Germany (Heywood and Jirjahn, 2009). These findings suggest that the effect of unions on the availability of family-friendly practices is likely to be more pronounced in Europe than in North America.

\subsubsection{Firm characteristics}

It is commonly believed that part-time employees are less likely to receive fringe benefits. I find that firms with a higher proportion of part-time permanent employees are statistically significant less likely to offer assistance for elder care and extended health care. The result for assistance for childcare is also negative but not statistically significant. By the same token, I find that firms with a higher proportion of part-time temporary employees are less likely to offer the three family-friendly practices, but the result is statistically significant only for assistance for elder care. I also find that workplaces with a higher proportion of contractual employees are less likely to offer assistance for childcare. These results are consistent with those reported in previous studies (e.g., Budd and Mumford, 2006; Heywood and Jirjahn, 2009). I lastly find that the proportion of managers in the workforce generally has a positive influence on the provision of assistance for childcare and elder care, perhaps reflecting that higher positions are associated with a higher probability of having more fringe benefits.

The results reveal that job training provision exhibits a positive and statistically significant effect on the three types of family-friendly practices. It is possible that firms that help employees with job training are able to bear the costs of training as well as the costs of the provision of family-friendly practices. Another plausible explanation for this result is that firms invest in employees through job training perhaps to retain their high-quality employees, which may lead to providing them more fringe benefits. Interestingly, I find that firms that have difficulty in filling vacant positions are more likely to offer assistance for childcare and elder 
care, indicating that perhaps firms use family-friendly programs to reduce labour market tightness.

Lastly, the estimated marginal effect on the firm size variable is positive and statistically significant. Indeed, it is commonly argued that larger firms have more organized human resources management and tend to provide more fringe benefits perhaps because of the unpleasant working environment due to increasing labour divisions and impersonal working atmosphere (Masters, 1969: 342; Schmidt and Zimmerman, 1991: 705). In addition, large firms are more likely to bear the costs of such practices than are smaller ones.

\subsubsection{Unobserved worker and firm characteristics}

The estimates for the unobserved heterogeneity distribution are presented in the last panel of Table 4. Worker effect can be interpreted as a measure of unobserved characteristics (e.g., different preferences, ability, motivation, ambition) that vary between employees and may affect the probability of having family-friendly practices. Firm effect is a measure of firm-specific unobserved characteristics common to all workers of the same workplace.

The values of the unobserved firm heterogeneity are found to be positive and statistically significant, indicating that assistance for childcare, assistance for elder care and extended health care are positively correlated. Thus, for example, firms that offer assistance for childcare simultaneously offer assistance for elder care and extended health care. However, I find that the values the of the unobserved worker heterogeneity are not statistically significant for assistance for childcare or assistance for elder care. These results indicate that unobservable firm characteristics have more significant effects than unobservable worker characteristics on the

firms' probability to provide family-friendly practices. These results could be explained by Rebitzer and Taylor's (1995) model on the role played by unobservable (to the firm) worker heterogeneity in analyzing how firms respond to worker preferences regarding wage-working hours-fringe benefits. They note that work preferences are heterogeneous and unobserved by the firm; therefore, working hours and fringe benefits tend to be set by the firm. Consequently, one can assume that unobserved firm characteristics may play an important role in explaining the provision of family-friendly practices. 


\subsection{Availability of family-friendly practices and wages}

Turning to the estimation of the relationship between the availability of family-friendly practices and wages, I use the Two Stages Least Squares (2SLS) method to solve the problem of simultaneity in which the availability of family-friendly practices is determined simultaneously with wages. Table 5 presents the 2SLS estimates without control variables while Table 6 includes standard controls for worker, job and firm characteristics. The results suggest a stronger negative pattern. I find that assistance for childcare, elder care and extended health care are associated with a reduction in workers' wages when all control variables are excluded. This result is also confirmed when I run the full specifications that include all control variables. The results provide strong evidence for the existence of a hedonic equilibrium in which workers face an implicit reduction in their wages. These results are consistent with those found in some previous studies (e.g., Baughman et al,. 2003; Eriksson and Kristensen, 2011; Heywood et al., 2007). I argue that the existence of a hedonic equilibrium could be explained by the theory that considers wages as a partial exchange of gifts between workers and firms (Akerlof, 1982). According to this theory, fringe benefits are to some extent perceived as a gift or a signal that employers care about employees' family responsibilities, and in return, employees are willing to pay to receive such practices. Eriksson and Kristensen (2011: 19) note that family-friendly practices are perceived as a means of meeting the special needs of employees; therefore, individuals are willing to pay for family-friendly practices regardless of the amount offered from such practices. Lastly, it is also possible that part of the negative effect of the availability of family-friendly practices could be related to the inherent differences between jobs that offer family-friendly practices and jobs that do not.

\section{Conclusion}

Family-friendly work practices have been introduced in the workplaces for some time, and surprisingly, their implications on workers have not been extensively analyzed by scholars in the context of the employee-employer relationship. This paper analyzes the determinants of the availability of three family-friendly work care practices and the impact of such practices on wages using linked employee-employer dataset. The empirical investigation improves on previous studies in two ways. I first use a correlated probit model for the determinants of the availability of family-friendly practices. Second, I take into account unobserved effects in the 
wage equation, leading to more accurate estimates.

The results emphasize that women are more likely to have assistance for childcare but less likely to have assistance for elder care. Perhaps surprisingly, the results indicate that immigrants are more likely to have assistance for childcare and elder care. These results could be explained by factors linked to labour supply and demand pressures that may lead firms to offer more or less than the optimal amount of family-friendly practices. Interestingly, I find that firms that have difficulty in filling vacant positions are more likely to offer assistance for childcare and elder care, indicating that perhaps firms use family-friendly programs to reduce labour market tightness.

Promoted workers, those who hold supervisory positions, the proportion of workforce managers and the highest level of education achieved tend to exert positive effects on firms' probability of providing the three types of family-friendly practices. Supervisors and managers are often overburdened by responsibilities, which may possibly lead them to spend more time at work and increase their demand for family-friendly practices. The positive effects of these covariates may also suggest that workers receive these practices informally as part of additional fringe benefits.

I find that unions have no impact on the availability of the three types of family-friendly practices, a result that underscores a similarity with previous findings from the U.S. but a difference from some studies from Europe (Britain and German). This result may suggest that the role of unions is more pronounced in North America than in Europe in regard to the design of family-friendly work policies.

The results also show that the provision of family-friendly practices is negatively correlated with worker wage, indicating the existence of a hedonic equilibrium. This result seems to support the view that better working conditions, including the provision of family-friendly practices, lead to the emergence of an implicit market in which firms offset the costs of providing such practices though lower wages. Heywood et al. (2007) use two measures for the availability of family-friendly practices. The first accounts for the employee's response to their firm's provision of such practices, whereas the second includes manager response. In my paper, I use the employee's response because it is the only available variable on the provision of family-friendly practices in the WES dataset. The results are similar to those of Heywood et al. (2007) only when they use workers' response to provide information on the provision of these 
practices. It is possible that the impact of the availability of such practices on wages depends on the source that reports this information, i.e., the employer or the employee. For example, when the information is provided by employees, it is possible that employees are better informed than managers about the availability of such practices, especially when these practices are considered non-pecuniary benefits and the amount offered may be specified in employment contracts.

Lastly, the results from this paper may have some policy implications. The enhancing effects of promotions received, supervisory positions, proportion of workforce managers and the highest level of education achieved seem to suggest that the provision of family-friendly practices should be improved through policies that facilitate the availability of such practices to workers from different occupations and job positions. The existence of a trade-off between family-friendly practices and earnings suggests that initiatives that tend to increase the provision of such practices may need to account for the differences in costs between firms that limit a good number of firms aiming to increase the availability of such practices. Indeed, if this trade-off is too large, the labour supply can decrease and firms may face difficulties in recruiting highly skilled workers. Moreover, firms may bear higher costs in hiring new employees, which may cause governments to increase the provision of these practices by subsidizing them, especially if the provision of such practices depends on the level of earnings reduction. 


\section{References}

Anderson, P. 1997. The Effect of Employer-Provided Health Insurance on Job Mobility: Job-Lock or Job-Push?, Dartmouth College.

Akerlof, George A. 1982. "Labor contracts as partial gift exchange." Quarterly Journal of Economics, 97 (4), 543-569.

Arthur, Michelle M., and Alison Cook. 2004. "Taking stock of work-family initiatives: how announcements of "family-friendly" human resource decisions affect shareholder value." Industrial and Labor Relations Review, 57 (4), 599-613.

Bardoel, Anne E., Simon A. Moss, Kosmas Smyrnios and Phyllis Tharenou. 1999. "Employee characteristics associated with the provision of work-family policies and programs." International Journal of Manpower, 20 (8), 563-577.

Baughman, Reagan, Daniela DiNardi and Douglas Holtz-Eakin. 2003. "Productivity and wage effects of family-friendly fringe benefits." International Journal of Manpower, 24 (3), 247-259.

Becker, Gary S. 1985. "Human capital, effort, and the sexual division of labor." Journal of Labor Economics, 3 (1): S33-S58.

Bloom, Nick, Tobias Kretschmer and John Van Reenen. 2011. "Are family-friendly workplace practices a valuable firm resource?” Strategic Management Journal, 32 (4), 343-367.

Budd, John W., and Angela M. Brey. 2003. "Unions and family leave: early experience under the family and medical leave act." Labor Studies Journal, 28 (3), 85-105.

Budd, John W., and Karen Mumford. 2004. "Trade unions and family friendly policies in Britain." Industrial and Labor Relations Review, 57 (2), 204-222.

Budd, John W., and Karen Mumford. 2006. "Family-friendly work practices in Britain: availability and perceived accessibility." Human Resource Management, 45 (1), 91-110.

Duncan, Greg J., and Frank Stafford. 1980. "Do union members receive compensating wage differentials?” American Economic Review, 70 (3), 355-371.

Duxbury, L. and Higgins, C. (2003). Work-life conflict in Canada in the new millennium: a status report. Health Canada.

Duxbury, L., Higgins, C. and Johnson, K. L. (1999). An examination of the implications and costs of work-life conflict in Canada. Health Canada.

Eriksson, Tor, and Nicolai Kristensen. 2011. Wages or fringes? Some evidence on trade-offs and sorting. Working Paper No. 001, Institute for Compensation Studies, Cornell University.

Evans, John M. 2001. Firms' contribution to the reconciliation between work and family life. 
Labour Market and Social Policy Occasional Papers No. 48, OECD, Paris.

Evans, John M. 2002. "Work/family reconciliation, gender wage equity and occupational segregation: the role of firms and public policy." Canadian Public Policy, 28 (1), S187-S216.

Gariety, Bonnie Sue, and Sherrill Shaffer. 2001. "Wage differentials associated with flextime." Monthly Labor Review, 124, 69-75.

Gray, Matthew, and Jacqueline Tudball. 2003. "Family-friendly work practices: differences within and between workplaces." Journal of Industrial Relations, 45 (3), 269-291.

Gruber, Jonathan, and Alan B. Krueger. 1991. "The incidence of mandated employer-provided insurance: lessons from workers' compensation insurance". Tax Policy and the Economy. D. Bradford, ed. MIT Press, Cambridge, MA, 111-144.

Heywood, John S., Stanley W. Siebert and Xiangdong Wei. 2007. "The implicit wage costs of family friendly work practices." Oxford Economic Papers, 59 (2), 275-300.

Heywood, John S., and Uwe Jirjahn. 2009. "Family-friendly practices and worker representation in Germany." Industrial Relations, 48 (1), 121-145.

Human Resources and Skills Development Canada. 2000. Work and family provisions in Canadian collective agreements. Edited by Charles Philippe Rochon.

Hwang, Hae-shin, Dale T. Mortensen and Robert W. Reed. 1998. "Hedonic wages and labor market search." Journal of Labor Economics, 16 (4), 815-847.

Johnson, Nancy Brown and Keith G. Provan. 1995. "The relationship between work/family benefits and earnings: a test of competing predictions." Journal of Socio-Economics, 24 (4), 571-584.

Lang, Kevin, and Sumon Majumdar. 2004. "The pricing of job characteristics when markets do not clear: theory and policy implications." International Economic Review, 45 (4), 1111-1128.

Masters, Stanley H. 1969. "An interindustry analysis of wages and plant size." Review of Economics and Statistics, 51 (3), 341-345.

O'Brien, Ellen. 2003. 'Employers' benefits from workers' health insurance." The Milbank Quarterly, 81 (1), 5-43.

Osterman, Paul. 1995. "Work/family programs and the employment relationship." Administrative Science Quarterly, 40 (4), 681-700.

Perry-Smith, Jill E., and Terry C. Blum .2001. "Work-family human resource bundles and perceived organizational performance." The Academy of Management Journal, 43 (6), 1107-1117. 
Rebitzer, James B., and Lowell J. Taylor. 1995. "Do labor markets provide enough short-hour jobs? An analysis of work hours and work incentives." Economic Inquiry, 33 (2), 257-273.

Rosen, Sherwin. 1974. "Hedonic prices and implicit markets: product differentiation in pure competition." Journal of Political Economy, 82 (1), 34-55.

Schmidt, Christoph M., and Klaus F. Zimmermann. 1991. "Work characteristics, firm size and wages." Review of Economics and Statistics, 73 (4), 705-710.

Senesky, Sarah. 2005. "Testing the intertemporal labor supply model: are jobs important?" Labour Economics, 12 (6), 749-772.

Valcour, M., Ollier-Malaterre, A., Matz-Costa , C., Pitt-Catsouphes, M., and Brown, M. 2011. "Influences on employee perceptions of organizational work-life support: Signals and resources.” Journal of Vocational Behavior, 79 (2), 588-559

Vistnes, J. P. (1997). Gender differences in days lost from work due to illness. Industrial and Labor Relations Review, 50: 304-323.

Whitehouse, G., and D. Zetlin. 1999. "Family-friendly policies: distribution and implementation in Australian workplaces." The Economic and Labour Relations Review, 10 (2), 221-239. 
Table 1: Analysis of variance in family-friendly work practices 1999-2005

\begin{tabular}{|c|c|c|}
\hline & Mean & Std. Dev. \\
\hline \multicolumn{3}{|l|}{ Childcare } \\
\hline Overall & 0.044 & 0.205 \\
\hline Between firms & & 0.058 \\
\hline Within firms & & 0.204 \\
\hline \multicolumn{3}{|l|}{ Elder care } \\
\hline Overall & 0.064 & 0.246 \\
\hline Between firms & & 0.123 \\
\hline Within firms & & 0.243 \\
\hline \multicolumn{3}{|l|}{ Extended health care } \\
\hline Overall & 0.421 & 0.268 \\
\hline Between firms & & 0.106 \\
\hline Within firms & & 0.267 \\
\hline Number of observations & \multicolumn{2}{|c|}{81,054} \\
\hline
\end{tabular}


Table 2: Summary statistics - Employees

\begin{tabular}{lrrrr}
\hline Variable & \multicolumn{3}{c}{1999} & \multicolumn{3}{c}{2005} \\
\hline & Mean & Std. Dev. & Mean & Std. Dev. \\
Socio-demographic characteristics & & & & \\
Women & 0.521 & 0.499 & 0.522 & 0.499 \\
Married & 0.566 & 0.495 & 0.531 & 0.450 \\
Black & 0.011 & 0.105 & 0.010 & 0.102 \\
Age & 39.637 & 11.064 & 40.902 & 11.902 \\
Immigrant & 0.175 & 0.380 & 0.179 & 0.383 \\
Number of children aged 0 to 18 & 0.779 & 1.040 & 0.680 & 0.987 \\
Single-parent & 0.127 & 0.333 & 0.118 & 0.323 \\
Total family income (000s) & 67993.080 & 55748.100 & 77033.62 & 54456.58 \\
No activity limitation due to health issues & 0.017 & 0.129 & 0.022 & 0.266 \\
Human Capital & & & & \\
Seniority & 8.428 & 8.192 & 8.748 & 8.740 \\
Experience & 16.183 & 10.713 & 17.569 & 11.500 \\
Vocational diploma or some college & 0.325 & 0.468 & 0.271 & 0.444 \\
Completed college or some university & 0.433 & 0.495 & 0.462 & 0.498 \\
Bachelor's degree or higher & 0.269 & 0.443 & 0.287 & 0.452 \\
Industrial training or other & 0.127 & 0.333 & 0.067 & 0.250 \\
Job characteristics & & & & \\
Work part-time & 0.201 & 0.401 & 0.209 & 0.406 \\
Work regular hours & 0.709 & 0.453 & 0.683 & 0.465 \\
Work from Monday to Friday & 0.254 & 0.435 & 0.780 & 0.414 \\
Work on a reduced work week & 0.139 & 0.346 & 0.069 & 0.253 \\
Work on compressed work week schedule & 0.085 & 0.279 & 0.080 & 0.271 \\
Promotion received & 0.381 & 0.485 & 0.376 & 0.484 \\
Supervise the work of other employees & 0.379 & 0.480 & 0.387 & 0.487 \\
Covered by a collective bargaining agreement & 0.280 & 0.449 & 0.261 & 0.439 \\
Occupation & & & & \\
Manager & 0.147 & 0.354 & 0.126 & 0.332 \\
Professional & 0.160 & 0.366 & 0.171 & 0.377 \\
Technician & 0.393 & 0.488 & 0.408 & 0.491 \\
Marketing/sales & 0.082 & 0.275 & 0.079 & 0.271 \\
Clerical/administrative & 0.141 & 0.348 & 0.147 & 0.354 \\
Production w/o certificate & 0.074 & 0.263 & 0.066 & 0.248 \\
Number of observations & 23,540 & & 24,197 & \\
\hline & & & &
\end{tabular}


Table 3: Summary statistics - Employers

\begin{tabular}{lcc}
\hline \hline Variable & \multicolumn{2}{c}{1999} \\
\hline & & Mean \\
\cline { 2 - 3 } Firm characteristics & & \\
Proportion of contractual workforce & 0.017 & 0.334 \\
Proportion of part-time permanent employees & 0.711 & 0.334 \\
Proportion of part-time temporary employees & 0.288 & 0.334 \\
Proportion of managers & 0.165 & 0.221 \\
Employer helping with training & 0.219 & 0.413 \\
Difficulty to fill vacant positions & 0.126 & 0.332 \\
Workplace size: & & \\
19 employees and less & 0.874 & 0.331 \\
20-99 employees & 0.108 & 0.310 \\
100-499 employees & 0.015 & 0.122 \\
500 employees and more & 0.002 & 0.047 \\
Industry & & \\
Natural resources & 0.018 & 0.135 \\
Primary product manufacturing & 0.010 & 0.100 \\
Secondary product manufacturing & 0.017 & 0.130 \\
Labour-intensive tertiary manufacturing & 0.030 & 0.173 \\
Capital-intensive tertiary manufacturing & 0.023 & 0.150 \\
Construction & 0.077 & 0.266 \\
Transportation & 0.121 & 0.326 \\
Communication and other utilities & 0.012 & 0.111 \\
Retail trade and consumer service & 0.317 & 0.465 \\
Finance and insurance & 0.052 & 0.222 \\
Real estate & 0.043 & 0.203 \\
Business services & 0.112 & 0.316 \\
Education and health services & 0.140 & 0.347 \\
Information and cultural industries & 0.022 & 0.146 \\
\hline Number of observations & \multicolumn{2}{c}{6,271} \\
\hline
\end{tabular}


Table 4: Determinants of family-friendly practices, simultaneous probit model

\begin{tabular}{|c|c|c|c|}
\hline & $(1)$ & $(2)$ & $(3)$ \\
\hline & Childcare & Elder care & Extended health care \\
\hline \multicolumn{4}{|l|}{ Socio-demographic characteristics } \\
\hline Women & $\begin{array}{c}0.139 * * * \\
(0.026)\end{array}$ & $\begin{array}{c}-0.269 * * * \\
(0.036)\end{array}$ & $\begin{array}{c}0.058 \\
(0.030)\end{array}$ \\
\hline Married & $\begin{array}{l}-0.044 \\
(0.029)\end{array}$ & $\begin{array}{c}-0.222 * * * * \\
(0.040)\end{array}$ & $\begin{array}{c}0.074 * * * \\
(0.034)\end{array}$ \\
\hline Black & $\begin{array}{l}-0.086 \\
(0.110)\end{array}$ & $\begin{array}{c}-0.149 \\
(0.150)\end{array}$ & $\begin{array}{c}-0.292 * * * \\
(0.110)\end{array}$ \\
\hline Age & $\begin{array}{l}-0.000 \\
(0.001)\end{array}$ & $\begin{array}{c}-0.001 \\
(0.001)\end{array}$ & $\begin{array}{c}0.001 \\
(0.001)\end{array}$ \\
\hline Age squared & $\begin{array}{c}0.000 \\
(0.000)\end{array}$ & $\begin{array}{c}-0.000 \\
(0.001)\end{array}$ & $\begin{array}{c}0.000 \\
(0.000)\end{array}$ \\
\hline Immigrant & $\begin{array}{c}0.123 * * * \\
(0.029)\end{array}$ & $\begin{array}{c}0.157 * * * \\
(0.040)\end{array}$ & $\begin{array}{c}0.001 \\
(0.034)\end{array}$ \\
\hline Number of children aged 0 to 18 & $\begin{array}{c}-0.044 * * * \\
(0.012)\end{array}$ & $\begin{array}{c}-0.015 \\
(0.016)\end{array}$ & $\begin{array}{l}-0.005 \\
(0.014)\end{array}$ \\
\hline Single-parent & $\begin{array}{l}-0.048 \\
(0.043)\end{array}$ & $\begin{array}{l}-0.104 \\
(0.057)\end{array}$ & $\begin{array}{c}0.074 \\
(0.047)\end{array}$ \\
\hline Total family income (000s) & $\begin{array}{c}0.000 * * * \\
(0.000)\end{array}$ & $\begin{array}{c}0.000 * * * \\
(0.000)\end{array}$ & $\begin{array}{c}0.000 \\
(0.000)\end{array}$ \\
\hline No activity limitation due to health issues & $\begin{array}{l}-0.010 \\
(0.044)\end{array}$ & $\begin{array}{c}0.016 \\
(0.060)\end{array}$ & $\begin{array}{c}0.036 \\
(0.048)\end{array}$ \\
\hline \multicolumn{4}{|l|}{ Human Capital } \\
\hline Seniority & $\begin{array}{l}-0.000 \\
(0.001)\end{array}$ & $\begin{array}{c}0.001 \\
(0.001)\end{array}$ & $\begin{array}{c}-0.001 \\
(0.001)\end{array}$ \\
\hline Seniority squared $(/ 100)$ & $\begin{array}{c}0.000 * * * \\
(0.000)\end{array}$ & $\begin{array}{c}0.000 * * * \\
(0.000)\end{array}$ & $\begin{array}{c}0.000 * * * \\
(0.000)\end{array}$ \\
\hline Experience & $\begin{array}{c}0.007 \\
(0.003)\end{array}$ & $\begin{array}{c}-0.015^{* * *} \\
(0.005)\end{array}$ & $\begin{array}{c}0.001 \\
(0.004)\end{array}$ \\
\hline Experience squared (/100) & $\begin{array}{l}-0.000 \\
(0.000)\end{array}$ & $\begin{array}{c}0.000 * * * \\
(0.000)\end{array}$ & $\begin{array}{l}-0.000 \\
(0.000)\end{array}$ \\
\hline Vocational diploma or some college & $\begin{array}{l}-0.015 \\
(0.025)\end{array}$ & $\begin{array}{c}-0.028 \\
(0.035)\end{array}$ & $\begin{array}{c}-0.005 \\
(0.028)\end{array}$ \\
\hline Completed college or some university & $\begin{array}{c}0.037 \\
(0.023)\end{array}$ & $\begin{array}{c}0.012 \\
(0.031)\end{array}$ & $\begin{array}{c}-0.032 \\
(0.027)\end{array}$ \\
\hline Bachelor's degree or higher & $\begin{array}{l}-0.045 \\
(0.027)\end{array}$ & $\begin{array}{c}0.108 * * * \\
(0.035)\end{array}$ & $\begin{array}{c}0.090 * * * \\
(0.035)\end{array}$ \\
\hline Industrial training or other & $\begin{array}{c}0.043 \\
(0.034)\end{array}$ & $\begin{array}{c}0.087 \\
(0.046)\end{array}$ & $\begin{array}{c}-0.019 \\
(0.040)\end{array}$ \\
\hline \multicolumn{4}{|l|}{ Job characteristics } \\
\hline Work part-time & $\begin{array}{c}-0.159 * * * \\
(0.048)\end{array}$ & $\begin{array}{c}-0.275^{* * *} \\
(0.064)\end{array}$ & $\begin{array}{c}-0.230 * * * \\
(0.057)\end{array}$ \\
\hline Work regular hours & $\begin{array}{l}-0.046 \\
(0.029)\end{array}$ & $\begin{array}{c}0.053 \\
(0.039)\end{array}$ & $\begin{array}{c}0.068 * * * \\
(0.034)\end{array}$ \\
\hline Work from Monday to Friday & $\begin{array}{c}0.044 \\
(0.038)\end{array}$ & $\begin{array}{c}0.097 \\
(0.050)\end{array}$ & $\begin{array}{c}0.040 \\
(0.039)\end{array}$ \\
\hline
\end{tabular}


Work on a reduced work week

Work on compressed work week schedule

Promotion received

Supervise the work of other employees

Covered by a collective bargaining agreement

\section{Firm characteristics}

Proportion of contractual workforce

Proportion of part-time permanent employees

Proportion of part-time temporary employees

Proportion of managers in the workforce

Employer helping with training

Difficulty to fill vacant positions

Workplace size:

20-99 employees

100-499 employees

500 employees and more

$\begin{array}{ccc}-0.043 & 0.048 & 0.103 * * * \\ (0.038) & (0.049) & (0.046) \\ 0.173 * * * & 0.120 * * * & -0.038 \\ (0.043) & (0.058) & (0.048) \\ 0.242 * * * & 0.248 * * & 0.082 * * * \\ (0.024) & (0.034) & (0.028) \\ 0.098 * * * & 0.097 * * * & 0.009 \\ (0.024) & (0.033) & (0.029) \\ 0.046 & 0.046 & 0.055 \\ (0.028) & (0.036) & (0.033)\end{array}$

$-0.061 * * *$

(0.027)

$-0.099$

$(0.069)$

$-0.058$

$(0.063)$

$0.263 * * *$

(0.067)

$0.194 * * *$

$(0.030)$

$0.076 * * *$

(0.024)

$0.258^{* * * *}$

$(0.041)$

$0.482 * * *$

$(0.045)$

$0.611 * * *$

(0.051)

\section{Constant}

Unobserved worker heterogeneity

Unobserved firm heterogeneity

$\begin{array}{clc}-4.086 * * * & -4.305 * * * & 4.791 * * * \\ (0.171) & (0.313) & (0.755) \\ -0.089 & -0.183 & 1.599 * * * \\ (0.064) & (0.116) & (0.310) \\ 0.894 * * * & 1.662 * * * & 0.273 * * * \\ (0.037) & (0.106) & (0.128)\end{array}$

(0.128)

$\begin{array}{cc}0.007 & 0.070 \\ (0.063) & (0.052) \\ -0.287 * * * & -0.171 * * * \\ (0.087) & (0.070) \\ -0.446 * * * & -0.092 \\ (0.088) & (0.069) \\ 0.345 * * * & 0.092 \\ (0.094) & (0.076) \\ 0.241 * * * & 0.072 * * * \\ (0.042) & (0.029) \\ 0.289 * * * & -0.746 \\ (0.036) & (0.125)\end{array}$

$0.187 * * *$

0.014

(0.037)

0.037

(0.042)

(0.069)

$0.193 * * *$

(0.057)

(0.088)
Number of observations

Industry dummies (14)

Occupation dummies (6)

Year dummies (7)

Notes: Statistical significance: $*=10 \%$; $* *=5 \% ; * * *=1 \%$. Robust standard error in parentheses.

The reference category for firm size is 19 employees and less. 
Table 5: The effect of the availability of family-friendly practices on wages (Initial estimates), 2SLS

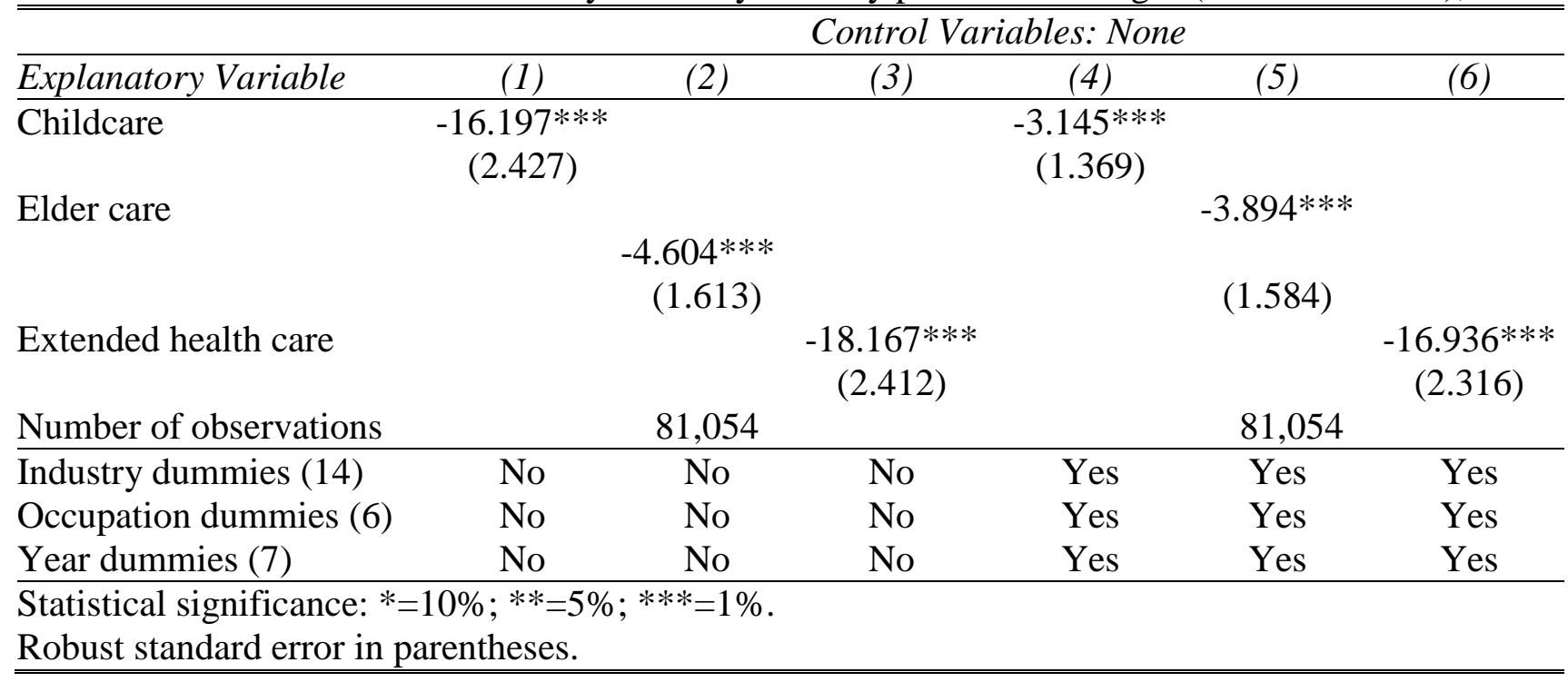


Table 6: The effect of the availability of family-friendly practices on wages (Full model), 2SLS

Control Variables:

Employee and firm characteristics

Explanatory Variable

(1)

Childcare

$-2.399 * * *$

(2)

Elder care

(1.045)

Extended health care

$-3.089 * * *$

$$
\text { (1.010) }
$$

Black

$-0.243$

$(0.180)$

Age

0.002

$(0.003)$

Immigrant

0.062

(0.072)

Single-parent

0.022

$(0.056)$

Total family income (000s)

$0.000 * * *$

$(0.000)$

No activity limitation due to health issues

Seniority

$0.482 * * *$

$(0.076)$

$-0.031^{* * *}$

$(0.007)$

Seniority squared (/100)

Experience

$0.001 * * *$

$(0.000)$

$0.033 * * *$

$(0.011)$

Experience squared (/100)

Vocational diploma some college

Completed college or some university

Bachelor's degree or higher

Industrial training or other

Work part-time

$-0.001 * * *$

$(0.000)$

$-0.293 * * *$

$(0.060)$

$0.226 * * *$

(0.056)

$1.029 * * *$

(0.067)

$-0.199 * * *$

(0.068)

$-1.015^{* * *}$

(0.095)

Work regular hours

$-0.188$

$(0.196)$

0.003

(0.004)

$0.469 * * *$

(0.074)

0.031

(0.055)

$0.000 * * *$

$(0.000)$

$0.608 * * *$

(0.102)

$-0.031^{* * *}$

(0.008)

$0.001 * * *$

$(0.000)$

$0.051 * * *$

(0.051)

0.000

(0.000)

$-0.307^{* * *}$

(0.060)

$0.226 * * *$

(0.055)

$.925^{* * *}$

(0.069)

$-0.152^{* * * *}$

$(0.067)$

$-1.006^{* * *}$

(0.089)

$0.740 * * *$

(0.054)
$-11.872 * * *$

(3.710)

$-0.671^{* * *}$

$(0.230)$

$-0.005$

(0.004)

$-0.057$

(0.054)

0.012

(0.062)

$0.000 * * *$

(0.000)

$0.490 * * *$

(0.082)

$-0.024 * * *$

(0.008)

$0.001 * * *$

(0.000)

$0.079 * * *$

(0.011)

$-0.001 * * *$

(0.000)

-0.280 ***

(0.069)

$0.337 * * *$

(0.065)

$1.270 * * *$

(0.101)

$-0.075$

(0.081)

$-1.481^{* * *}$

(0.215)

$0.811 * * *$

(0.069) 
Work from Monday to Friday

$\begin{array}{ccc}-0.070 & -0.082 & 0.308 * * * \\ (0.065) & (0.064) & (0.127) \\ -0.028 & -0.031 & -0.092 \\ (0.097) & (0.101) & (0.100) \\ -0.299 * * * & -0.287 * * * & -0.025 \\ (0.063) & (0.063) & (0.096) \\ 1.211 * * * & 1.197 * * * & 1.354 * * * \\ (0.044) & (0.041) & (0.061) \\ 0.347 * * * & 0.341 * * * & 0.413 * * * \\ (0.048) & (0.056) & (0.063) \\ 0.295 * * * & 0.279 * * * & 0.261 * * * \\ (0.044) & (0.049) & (0.045)\end{array}$

Workplace size:

20-99 employees

$0.122 \quad 0.176 * * * \quad 0.199 * * *$

100-499 employees

(0.096)

(0.072)

$0.170 *$

$0.273 * * *$

(0.093)

(0.100)

(0.075)

$0.358 * * *$

500 employees and more

$0.403 * * *$

$0.261 * * *$

(0.100)

$(0.135)$

(0.084)

$0.518 * * *$

Number of observations 81,054

Industry dummies (14)

Occupation dummies (6)

Yes

(0.127)

Year dummies (7)

Yes

Yes

Yes

Yes

Yes

Yes

Yes

Yes

Statistical significance: $*=10 \% ; * *=5 \% ; * * *=1 \%$.

Robust standard error in parentheses. 